\title{
Diversity and Abundance of Natural Enemies of Helopeltis antonii in Cocoa Plantation Related with Plant Pattern and Insecticide Application
}

\author{
Mochamad Syarief $^{(*)}$, Agung Wahyu Susilo2), Toto Himawan ${ }^{3)}$, and A. Latief Abadi ${ }^{3)}$ \\ ${ }^{1)}$ State Polytechnic of Jember, Jl. Mastrip, Jember, Indonesia \\ ${ }^{2}$ Indonesian Coffee and Cocoa Research Institute, Jl. P.B. Sudirman 90, Jember, Indonesia \\ ${ }^{3}$ Faculty of Agriculture, University of Brawijaya, Jl. Veteran, Malang, Indonesia \\ ${ }^{*}$ Corresponding author: m_syarief@polije.ac.id
}

\begin{abstract}
Natural enemy is an important factor in management of cacao pests. One way to increase its diversity and abundance is through agroecosystem management techniques that support. The study was conducted for one year from February 2014 to February 2015 in Banjarsari Plantation and a cocoa farm of Kaliwining Experimental Station, Jember, which applied different cropping patterns and use of insecticides. The purpose of this research was to study the effect of cropping pattern and use of insecticide on diversity and abundance of predators, parasitoids, abundance and intensity of Helopeltis antonii attack. Observation of pests and natural enemies was done visually, using sweep net, yellow pan traps, malaise trap and pifall trap. Intensity of the attack used Pedigo \& Buntin equations. Diversity index used Shannon Diversity Index (H') and Simpson's dominance index (C). Differences in predator abundance, parasitoid, air temperature, relative humidity, light intensity and rainfall used Wilcoxon test. Results of this study showed that monoculture and intensive use of synthetic insecticides caused lower diversity and abundance of predators and parasitoids, while the abundance and intensity of $H$. antonii attacks were higher compared with polyculture without insecticide. Banjarsari cocoa plantation that applied monoculture and intensive use of synthetic insecticides, had lower diversity and abundance predators and parasitoids compared with cocoa plantation in Kaliwining that applied polyculture planting without using insecticide. Dominant predators in Banjarsari and in Kaliwining cocoa plantations were Dolichoderus thoracicus and Araneus diadematus, while dominant parasitoid in Banjarsari and in Kaliwining cocoa plantations was Araneus diadematus.
\end{abstract}

Keyword: Cocoa agroecosystem, Helopeltis antonii, insecticide, natural enemies, planting patterns, predator, parasitoid

\section{INTRODUCTION}

Cocoa (Theobroma cacao L.) is an important commodity for Indonesian plantation. Accor-ding to data from the International Cocoa Organization (ICCO) (2015), Indonesia is the biggest cocoa producer in Oceania.
Helopelthis antonii is an obstacle in the cultivation of cocoa. Beside attacking cocoa pods, it also attacks shoots. Severe attack on shoots can reduce yields of cocoa by $36-75 \%$ (Sulistyowati \& Mufrihati, 2006). Some cocoa plantation companies in Indonesia manage their plantations with monoculture 
cropping pattern with intensification of synthetic insecticide use to control the main pests of cocoa plants. Several synthetic insecticides used for the main crop pest control (H. antonii and Hyposidra talaca) are insecticides with active ingredient of alphacypermethrin $50 \mathrm{~g} / \mathrm{L}$ with concentration 0.02 , BPMC $500 \mathrm{~g} / \mathrm{L}$ active ingredient, with concentration $0.02 \%$ applied take turns. The dose used is 500 liters per hectare. Dosage and concentration may change based on efficacy test results (Syarief, 2016).

Based on the work program of ICCO (2015), there has been a program of reduction of pesticide residue hazard in cocoa beans. This program is conducted to maintain market access in accordance with the standards and regulations issued by cocoa importing countries (ICCO, 2013). Therefore, efforts should be made to reduce the use of synthetic insecticides in cocoa pest management by considering the role of natural enemies in form of predators and pararasitoids. It is necessary to study the diversity and abundance of natural enemies of $H$. antonii in various agroecosystem management of cocoa. The results of which are expected to be used as a solution to optimize the synergy between the various components of Integrated pest management, so that the stability of the agroecosystem can be improved. Natural enemies have important roles in the structure and processes in maintaining the biological diversity of an ecosystem (Price, 1997). Agroecosystem management factors affect the diversity of natural enemies (Mattson et al., 1984; Altieri, 1989; Letourneau \& Altieri, 1999). Swift et al. (1996) suggests that biodiversity in agroecosystems can be used as a pest control concept.

This research aimed to determine the effect of cocoa cropping pattern and insecticide applications on diversity and abundance of predators, parasitoids, abundance and intensity of $H$. antonii attack.

\section{MATERIALS AND METHODS}

This study in form of survey research was conducted since February 2014 to February 2015 in two locations of cocoa plantations at Jember District that apply different pest management i.e. Banjarsari Plantation and Kaliwining Experimental Station of ICCRI. Banjarsari was located at $50 \mathrm{~m}$ asl. Kaliwining was located at $45 \mathrm{~m}$ asl. Both locations belonged to climate type D according to Schmidt-Ferguson classification. Cocoa plant population was 770 plants/ha. The clones of cocoa plants were: DR 1 , DR2, DR38 and DRC with planting year of 2008, monoculture cropping pattern. Shade tree were Leucaena leucocephala and coconut trees. The population of $L$. leucocephala were 555 trees per hectare and coconut 92 trees per hectare. The clones of cocoa plants at Kaliwining were DR 1, DR 2, DR 38, and DRC with cocoa plant population were 200 plants of planting year 2008, polyculture cropping pattern. Cacao trees were planted among tree species with irregular spacing: coconut (Cocos nucifera), breadfruit (Artocarpus altilis), starfruit (Averrhoa carambola), lime (Citrus hystrix), Morinda citrifolia, banana (Musa paradisiaca), Nauclea orientalis, teak (Tectona grandis), Chrysophyllum cainito), guava (Psidium guajava), papaya (Carica papaya), bamboo (Bambusa sp.), jackfruit (Artocarpus heterophyllus) and cassava (Manihot utilissima).

In Banjarsari plantation, synthetic insecticide used was an active ingredient of alphacypermethrin $50 \mathrm{~g} / \mathrm{L}$ with a concentration of $0.02 \%$, BPMC $500 \mathrm{~g} / \mathrm{L}$ active ingredient, with $0.02 \%$ concentration applied by turns with dose used of $500 \mathrm{~L} / \mathrm{ha}$. Meanwhile Kaliwining cocoa plantation applied polyculture without insecticides. Sampling of plants in Banjarsari systematically two-dimensional cacao plant located on the row and second lane as the first sample. The next sample was toward the row 
and the one-hose lane of a plant (Mudjiono, 1987). Sampling in Kaliwining was done randomly according to the condition of plants. The sample plant population was 200 plants in each location. The collected data were species of natural enemies, temperature, humidity and light intensity done every week for a year. Natural enemies observations were done visually using sweep nets, yellow pan traps, malaise traps and pitfall traps carried out every week for a year. In visual observations, presence of $H$. antonii and natural enemies species observed surrounding a sample plant with attacked pods or new shoots. Sweep net was used by swinging between the lines of cocoa plants into the shelter of natural enemies. Yellow pan traps containing a solution of water and detergent was placed one meter above the ground, for 24 hours, a distance of $20 \mathrm{~m}$ and a total of 20 traps per cocoa plantation. Pitfall traps containing a solution of water and detergent was laid flat on the ground, for 24 hours, a distance of $20 \mathrm{~m}$ and total of 20 traps per cocoa plantation. One malaise trap per site was placed in the middle of the plantation, for 24 hours.

Measurement of temperature and humidity using the Thermo/hygro/clock VICTOR VC 230 Series, which was placed at $1.5 \mathrm{~m}$ above the ground. The intensity of the light was measured using MASTECH brand Lux meter, MS 6612 Series, which was laid on the ground (Klein et al., 2001). The observation was done between 08.00 A.M. until 11.00 A.M. every week. Daily rainfall data was obtained from the nearest climatological station.

Identification of $H$. antonii predator and parasitoid was done at Jember Polytechnic Plant Protection Laboratory until species level using Pests of Crops in Indonesia by Kalshoven (1981), Manual of Nearctic Diptera (McAlpine, 1987). Identification of several species was done with taxonomic assistance at the Zoology Museum, Indonesian Institute of Sciences, Bogor.

The data of abundance and intensity of $H$. antonii attack were shown in box-plot form. Different parameters of predator species abundance, parasitoid, environmental parameters i.e. air temperature, humidity, light intensity and rainfall and diversity index using Wilcoxon Test. Relationship between predator abundance, parasitoid and $H$. antonii, environmental parameters and attack intensity using Spearman correlation. Overall data analysis using SPSS software version 15 . The intensity of $H$. antonii attack use the Pedigo \& Buntin equation (2003) as follows:

$$
\mathrm{P}=\mathrm{a} / \mathrm{b} \times 100 \%
$$

$\mathrm{P}$ is the intensity of affected plants (\%), $a$ is the number of affected plants and $b$ is the total plant observed. The diversity index is calculated by the Shannon-Wiener formula:

$$
\mathrm{H}=-\Sigma \frac{\mathrm{s}}{\mathrm{i}=1 \mathrm{~N}} \log \frac{\mathrm{ni}}{\mathrm{N}}
$$

where $\mathrm{H}$ is the diversity index of Shannon, ni is the total individual species $\mathrm{i}, \mathrm{N}$ is the total individual of all species. Criteria for the Shanon-Wiener diversity index is explained by Krebs (1989).

Simpson's dominance index is to know the dominance of certain species, using the formula:

$$
\mathrm{C}=\Sigma\left(\frac{\mathrm{ni}}{\mathrm{N}}\right)^{\wedge} 2
$$

where $\mathrm{C}$ is the index value of dominance, $\mathrm{ni}$ is the number of individuals in one species, $\mathrm{N}$ is the total number of individual species found. Odum (1993) stated that the criterion of dominance is as follows: if the value of $\mathrm{C}$ approaches $0(<0.5)$, then no species 
predominate. If the value of $\mathrm{C}$ approaches $1(\geq 0.5)$, then there is a dominating species.

\section{RESULTS AND DISCUSSION}

Based on the survey, diversity and abundance of $H$. antonii predators in Banjarsari plantation found 5 orders, 8 families and 8 species, while at Kaliwining plantation found 6 orders, 11 families and 11 species (Table 1). Diversity and abundance of $H$. antonii parasitoids in Banjarsari plantation found 2 orders, 4 families and 4 species, while at Kaliwining plantation found 2 orders, 6 families and 6 species (Table 2). Based on the Table 1 and Table 2, the abundance of $H$. antonii predators in Banjarsari plantation between Banjarsari and Kaliwining are different. Banjarsari is higher than Kaliwining. It is caused by several factors i.e. cropping patterns and the use of insecticides. This is due to the availability of food for species of natural enemies. Cropping factor relates to the ability of agro-ecosystem in providing food for survival and breeding species. Monoculture can provide very minimal availability of food for species of predators, parasitoids. Meanwhile, polyculture does not provide plants that are focused on a particular species, so that the population of predators, parasitoids on polyculture is in balance. According to Jervis et al. (2004), monoculture can reduce the number and activity of natural enemies due to limited source of food. For example, pollen, nectar and prey or alternative hosts need natural enemies to eat and breed as well as a place for refugia and survive in the agro-ecosystem. Dryer \& Landis (1996) and Idris et al. (2002) similarly argue that polyculture provides a variety of resources such as alternative hosts, food, shelter, where appropriate, pollen and nectar (Plowright et al., 1993), cultivation near wild vegetation (Menalled et al., 1999), shade (Davis et al., 2001), vegetation as a breeding ground of natural enemies (Karindah et al., 2011a, 2011b). Nurindah \& Sunarto (2008) state that a polyculture system on agro-ecosystem has a more varied crop diversity, and the diversity and population of natural enemies (parasitoids and predators) are relatively high.

Natural enemies diversity in Banjarsari that apply synthetic insecticide, shows the lower number of natural enemies species than Kaliwining. Number of predators and parasitoids in Banjarsariis lower than Kaliwining (Table 2 and Table 3). Application of synthetic insecticides can kill predators and parasitoids, that were not the targeted

Table 1. Diversity and abundance of predators of $H$. antonii in Banjarsari and Kaliwining cocoa plantations

\begin{tabular}{|c|c|c|c|}
\hline Order/Family & Species & Banjarsari (Mean \pm SD) & Kaliwining (Mean \pm SD) \\
\hline \multicolumn{4}{|l|}{ HYMENOPTERA } \\
\hline Vespidae & Vespa affinis & $6.19 \pm 8.54 \mathrm{a}$ & $4.67 \pm 6.25 \mathrm{~b}$ \\
\hline Formicidae & Dolichoderus thoracicus & $31.06 \pm 0.33 \mathrm{a}$ & $62.167 \pm 0.983 b$ \\
\hline \multicolumn{4}{|l|}{ COLEOPTERA } \\
\hline Coccinellidae & Coccinella transversalis & $6.67 \pm 10.75 \mathrm{a}$ & $17.89 \pm 11.47 b$ \\
\hline \multicolumn{4}{|l|}{ MATODEA } \\
\hline Mantidae & Mantis religiosa & $2.07 \pm 1.64 \mathrm{a}$ & $14.44 \pm 11.32 b$ \\
\hline \multicolumn{4}{|l|}{ ARAENAE } \\
\hline Lycosidae & Araneus diadematus & $18.69 \pm 30.52 \mathrm{a}$ & $23.05 \pm 20.82 b$ \\
\hline Tetragnathidae & Leucauge decorata & $0.00 \mathrm{a}$ & $2,00 \pm 1,41 \mathrm{~b}$ \\
\hline Linyphiidae & Pardosa pseudoannulata & $3.00 \pm 2,65 \mathrm{a}$ & $1.07 \pm 0.37 \mathrm{~b}$ \\
\hline Oxyopidae & Peucetia longipalpis & $1.00 \pm 0.00 \mathrm{a}$ & $4.08 \pm 2.48 \mathrm{~b}$ \\
\hline \multicolumn{4}{|l|}{ ODONATA } \\
\hline Libellulidae & Orthetrum testaceum & $2.59 \pm 1.58 \mathrm{a}$ & $4,26 \pm 3.88 b$ \\
\hline Calopterygidae & Vestalis amoena & $0.00 \mathrm{a}$ & $6.85 \pm 7.63 b$ \\
\hline \multicolumn{4}{|l|}{ NEUROPTERA } \\
\hline Chrysopidae & Chrysopa oculata & $0.00 \mathrm{a}$ & $14.00 \pm 5.66 \mathrm{~b}$ \\
\hline
\end{tabular}


of insecticides. According to Arifin et al. (2011) and Amalin et al. (2009), an arthropod species and populations can be affected by pesticides. Pesticides indirectly affect through the food chain (Brown, 1987). Activities of predators and parasitoids can affect the susceptibility to insecticides. Predators and parasitoids are active and more susceptible to insecticides because of more frequent contacts with insecticide residues that stick to the surface of plants. Insecticides also can affect indirectly against predators for pest prey contaminated with insecticide.

The abundance and intensity of $H$. antonii attack in Banjarsari higher than Kaliwining (Figure 1 and Figure 2). Based on Spearman correlation analysis, the correlation coefficient between the abundance and intensity of $H$. antonii attack is $0.617^{* *}$. This can be affected by cropping patterns and the use of insecticides. Monoculture that applied in the Banjarsari can provide feed resources concentrated on $H$. antonii throughout the year. Meanwhile, polyculture in Kaliwining is no source of concentrated feed to $H$. antonii. Synthetic insecticide application can kill the natural enemies of $H$. antonii which was not a target. $H$. antonii predators populations i.e. Coccinella transversalis and Araneus diadematus in Banjarsari lower than Kaliwining. The populations of $C$. transversalis were 6.67 \pm 10.75 in Banjarsari and $17.89 \pm 11.47$ in Kaliwining. Populations of A. diadematus were $18.69 \pm 30.52$ in Banjarsari and 23.05 \pm 20.82 in Kaliwining. (Table 2.). Amalin et al. (2009) stated that the predator is mostly sensitive to insecticides from the family of Coccinellidae. Populations of C. transversalis and A. diadematus on the cocoa agro-ecosystem sprayed with synthetic insecticides were lower than that did not use insecticides.

Differences cropping pattern between Banjarsari and Kaliwining show the difference of temperature, humidity, and light intensity. This may lead to differences in $H$. antonii abundance. Spearman correlation analysis showed that between light intensity and $H$. antonii abundance was negatively correlated $(\mathrm{r}=-0.542 * *)$, humidity with $H$. antonii abundance was positively correlated $(\mathrm{r}=$ $0.201^{*}$ ). Rainfall with $H$. antonii abundance is positively correlated $\left(\mathrm{r}=-0.291^{* *}\right)$. The condition of the plantation which is more humid and the lower light intensity such as the condition at Banjarsari (Table 5) shows the of $H$. antonii abundance is higher than Kaliwining. Higher moisture conditions and

Table 2. Diversity and abundance of parasitoids of $H$. antonii in Banjarsari and Kaliwining cocoa plantations

\begin{tabular}{lcrr}
\hline Order/Family & Species & Banjarsari (Mean \pm SD) & Kaliwining (Mean \pm SD) \\
\hline HYMENOPTERA & & & \\
Braconidae & Psyttalia fletcheri & $18.81 \pm 25.61 \mathrm{a}$ & $37.30 \pm 30.67 \mathrm{a}$ \\
Platygastridae & Telenomus fariai & $1.25 \pm 0.44 \mathrm{a}$ & $7.90 \pm 12.32 \mathrm{a}$ \\
Braconidae & Euphorus helopeltidis & $2.00 \pm 0.00 \mathrm{a}$ & $7.90 \pm 12.32 \mathrm{a}$ \\
Braconidae & Apanteles sp. & $0.00 \mathrm{a}$ & $1.78 \pm 0.67 \mathrm{a}$ \\
Eulopidae & Oomyzus sokowskii & $0.00 \mathrm{a}$ & $2.20 \pm 2.44 \mathrm{a}$ \\
DIPTERA & Sarcophaga aurifrons & $1.727 \pm 1.032 \mathrm{a}$ & $2.903 \pm 1.248 \mathrm{a}$ \\
Sarcophagidae & aresigitio
\end{tabular}

Notes: Different letters in the same row, are significantly different according to the Wilcoxon test).

Table 3. Shannon diversity index $\left(\mathrm{H}^{\prime}\right)$ and dominance index $(\mathrm{C})$ in Banjarsari and Kaliwining cocoa plantations

\begin{tabular}{ccc}
\hline & & Plantation \\
\cline { 2 - 3 } Diversity index & Banjarsari $( \pm$ SD) & Kaliwining $( \pm$ SD $)$ \\
\hline$H^{\prime}$ & $1.690 \pm 0.413 \mathrm{a}$ & $2.608 \pm 0.544 \mathrm{~b}$ \\
$\mathrm{C}$ & $0.302 \pm 0.173 \mathrm{a}$ & $0.113 \pm 0.112 \mathrm{~b}$ \\
\hline Notes: Different letters in the same row, are significantly different according to the Wilcoxon test).
\end{tabular}

Notes: Different letters in the same row, are significantly different according to the Wilcoxon test). 


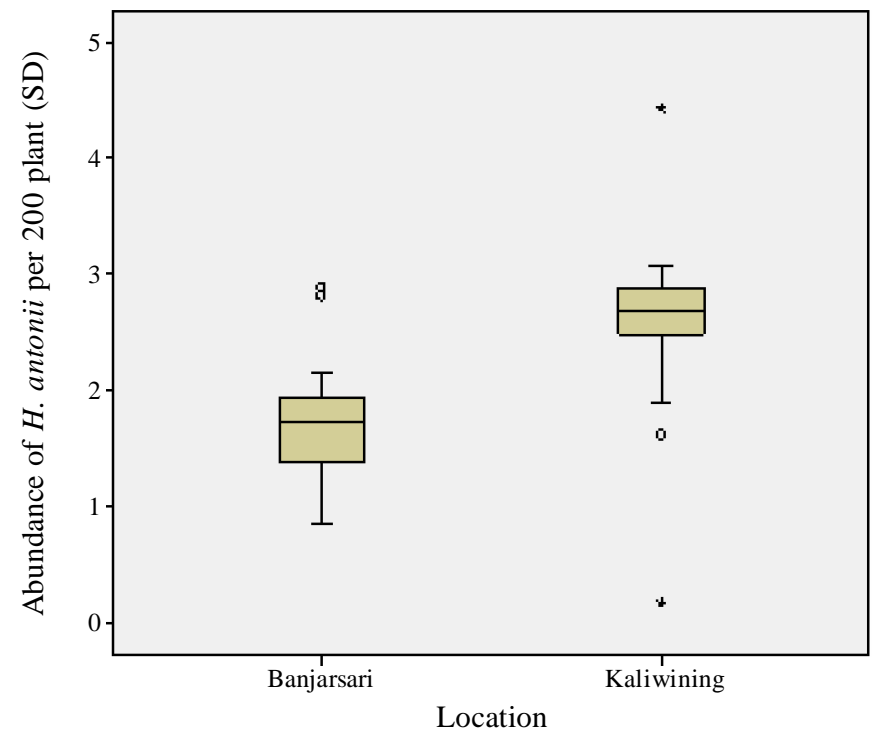

Figure 1. Abundance of $H$. Antonii

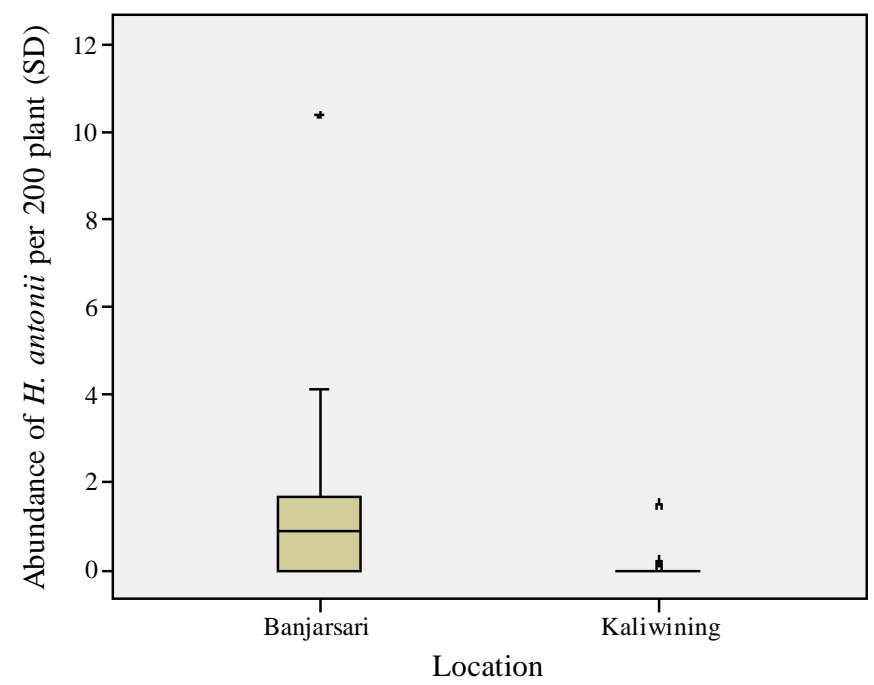

Figure 2. Intensity of $H$. antonii attack

lower light intensity will benefit the development of $H$. antonii. Helopeltis antonii prefer humid, and low temperature conditions but not for high light intensity. Fluctuations in insect populations of the genus Helopeltis are highly sensitive to direct sunlight (Kalshoven, 1981). Conditions of high rainfall will inhibit the movement of $H$. antonii. According to research results of Karmawati et al. (1999) in Wonogiri \& Karmawati et al. (2010) in West Lombok states that the population and appearance of $H$. antonii is determined by rainfall and micro moisture. The high indicator of $H$. antonii abundance in Banjarsari is indicated by Shannon diversity index which is lower than Kaliwining and dominance index which is higher than Kaliwining (Table 4). 
Table 4. The average of temperature, humidity, light intensity and rainfall in Banjarsari and Kaliwining cocoa plantations

\begin{tabular}{|c|c|c|c|}
\hline \multirow{2}{*}{ Microclimate } & \multicolumn{3}{|c|}{ Plantation } \\
\hline & Banjarsari $( \pm$ SD) & \multicolumn{2}{|c|}{ Kaliwining ( \pm SD) } \\
\hline Temperature $\left({ }^{\circ} \mathrm{C}\right)$ & $31.93 \pm 2.48 \mathrm{a}$ & $31.59 \pm$ & $1.46 \mathrm{a}$ \\
\hline Humidity (\%) & $68.40 \pm$ & $66.42 \pm$ & $6.39 \mathrm{a}$ \\
\hline Light intensity (Lux) & $6,814.60 \pm 687.71 \mathrm{a}$ & $19,737.60 \pm$ & $05.04 \mathrm{~b}$ \\
\hline Rainfall (m.m) & $54.14 \pm 68.78 b$ & $39.96 \pm$ & $75.01 \mathrm{a}$ \\
\hline
\end{tabular}

Notes: Mean followed by different letters in the same row is significantly different according to the Wilcoxon test

The lower diversity of species in agroecosystems, the higher species abundance. This is caused by the dominance of $H$. antonii in Banjarsari cocoa plantation. This is in accordance with Price (1997) opinion, which states that if the high diversity of the type of dominance of a species is low. The lower diversity of species in the agroecosystem, resulted in higher species abundance. This is caused by the dominance of $H$. antonii in Banjarsari. This is in accordance with Price (1997) opinion, which states that if diversity is high then the degree of dominance of a species is low.

\section{CONCLUSIONS}

Monoculture and intensive use of synthetic insecticides, showing lower diversity and abundance predators and parasitoids, while the abundance and intensity of $H$. antonii attacks were higher than polyculture without insecticide. Banjarsari cocoa plantation that apply monoculture and intensive use of synthetic insecticides, showing lower diversity and abundance predators and parasitoids than Kaliwining cocoa plantation that apply the pattern of planting polyculture without using insecticide. The dominant predators in the Banjarsari and Kaliwining cocoa plantation were Dolichoderus thoracicus and Araneus diadematus, while the dominant parasitoid in Banjarsari and Kaliwining cocoa plantations was Araneus diadematus.

\section{ACKNOWLEDGEMENTS}

Gratitude is expressed to Directorate General of Higher Education for funding this study through Scholarship for Postgraduate Home Affairs, Fiscal year 2015.

\section{REFERENCES}

Altieri, M.A. (1989). Agroecology: A new research and development paradigm for word agriculture. Agriculture, Ecosystems, and Environment, 27, $37-46$.

Amalin, D.M.J; E. Pera; R. Duncan; J. Leavengood \& S. Koptur (2009). Effects of pesticides on the Arthropod Community in the agricultural areas near the Everglades National Park. Proceedings of Florida State Horticulture Society, 122, 429-437.

Arifin, M.; I.B.K. Suryawan; B.H. Priyanto \& A. Alwi (2011). Diversity of Arthropods in the various techniques of rice cultivation in Pemalang, Central Java. Food Crops Research, 15, 5-12.

Brown, A.W.A. (1987). Ecology of Pesticides. John Wiley and Sons Inc., New York.

Davis, A.J.; J.D. Holoway; H. Huijbregts; J. Krikken; A.H. Kirk-Spriggs \& S.L. Sutton (2001). Dung bettle as indicator of change in the forest Northen Borneo. Journal Applied Ecology, 38, 593-616.

Dryer, L.E. \& D.A. Landis (1996). Effect of habitat, temperature and sugar availability on longevity of Eriborus terebrans (Hym: Ichneumonidae) in corn fields. Environmental Entomology, 25, 1192-1201. 
Griffin, C.T.; D. Chaerani; A.P. Fallon, Reid \& M.J. Downes (2000). Occurrence and distribution of the entomopathogenic nematodes Steinernema spp. and Hetero rhabditisindica in Indonesia. Journal of Helminthology, 74, 143-150.

Idris, A.B.; S.M. Nor \& R. Rohaida (2002). Study on diversity of insect community at different altitudes of Gunung Nuang in Selangor, Malaysia. Journal of Biological Sciences, 2, 505-507.

ICCO (2015) Annual Report 2014/2015. International Cocoa Organization, London.

Jervis, M.A.; J.C. Lee \& G.E. Heimpel (2004). Use of behavioural and life-history studies to understand the effects of habitat manipulation. In: G.M. Gurr; S.D. Wratten \& M.A. Altieri (Eds.), Ecological Engineering for Pest Management. Comstock Publishing Associates, New York.

Kalshoven, L.G.E. (1981). Pests of Crops in Indonesia. (Revised and translated by P.A. van der Laan \& G.H.L. Rothschild). P.T. Ichtiar Baru-Van Hoeve, Jakarta.

Karindah, S.; A. Purwaningsih; A. Agustin \& L.P. Astuti (2011a). Ketertarikan Anaxipa longpennis Servile (Orthoptera: Gryllidae) terhadap beberapa jenis gulma di sawah sebagai tempat bertelur. Journal Entomologi Indonesia, 8, 27-35.

Karindah, S.; Y. Bagyo; S. Liliek \& P.T. Green (2011b). Abundanche of Metiochevit talicollis (Orthoptera: Gryllidae) and natural enemies in rice agroecosystem as influenced by weed species. Journal of Agrivita, 33, 133-141.

Klein, A.M.; I.S. Deventer \& T. Scharnke (2002). Predator-prey ratios on cocoa along a land-use gradient in Indonesia. Biodiversity and Conservation, 11, $683-693$

Karnawati, E.; Siswanto \& E.A. Wikardi (1999). Peranan semut (Oechophyla smaragdina dan Dolichoderus sp.) dalam pengendalian
Helopeltis sp. dan Sanurus indecora pada jambu mete. Jurnal Penelitian Tanaman Indonesia, 12, 1-7.

Karnawati, E.; Z. Mahmud; M. Syakir; J. Munarso; I.K. Ardana \& Rubiyo (2010). Budidaya dan Pascapanen Kakao. Pusat Penelitian dan Pengembangan Kakao. Bogor.

Krebs, C.J. (1989). Ecology: Experimental Analysis of Distribution and Abundance. 4 ed. Hoper International Ed., New York.

Letourneau, D.K. \& M.A. Altieri (1999). Biology of parasitic Hymenoptera. In: T.S. Bellows \& T.W. Fisher (Eds.), Handbook of Biological Control: Principles and Applications of Biological Control. Academic Press, San Diego.

Mattson P.C.; M.A. Altieri \& W.C. Gagne (1984). Modification of small farmer practice for better pest management. Annual Review of Entomology, 29, 303-402.

Menalled, F.D.; P.C. Marino; S.H. Gage \& D.A. Landis (1999). Does agricultural landscape structure affect parasitism and parasitoid diversity. Ecological Application , 9, 634-641.

Nurindah \& D.A. Sunarto (2008). Konservasi musuh alami serangga hama sebagai kunci keberhasilan PHT kapas. Balai Penelitian Tanaman Tembakau dan Serat, 7, 01-11.

Pedigo, L.P. \& G.D. Buntin (2003). Handbook of Sampling Methods for Arthropods in Agriculture. CRC Press, LondonTokyo.

Plowright, R.C.; J.D. Thomson; L.P. Lefkovitch \& C.M.S. Plowright (1993). An experimental study of the effect of colony resource level manipulation on foraging for polen by worker bumble bees. Canadian Journal of Zoology, 71, 1393-1396.

Price, P.W. (1997). Insect Ecology. (3 ${ }^{\text {rd }}$ Ed.) John Wiley and Sons Inc. New York, Chisheester, Weinkeim, Brisbane, Singapore, Toronto. 
Sulistyowati, E. \& Mufrihati (2006). Struktur dan fungsi antropoda pada ekosistem tanaman kakao. Warta Pusat Penelitian Kopi dan Kakao Indonesia, 22, 71-81.

Swift, M.J.; J. Vandermeer; P.S. Ramakrisnan; J.M. Anderson; C.K. Ong \& B.A. Hawkins (1996). Biodiversity and agroecosytem function. In: Functional Roles of Biodeversity : A Global Perspective (Eds. H.A. Hooney). John Wiley.
Syarief, M. (2016). Diversitas Arthropoda dan Status Helopeltis antonii pada Berbagai Pengelolaan Agroekosistem Kakao. Dissertasi. Fakultas Pertanian, Universitas Brawijaya, Malang, Indonesia.

$$
* * 0 * *
$$

